\title{
Pengaruh Daya Tarik Wisata dan Word Of Mouth terhadap Keputusan Wisata Berkunjung ke Taman Hutan Kota di Kota Langsa
}

\author{
Erni Junaida \\ Fakultas Ekonomi, Universitas Samudra, Langsa \\ e-mail: ernijunaida@unsam.ac.id
}

\begin{abstract}
The research intends to analyze the influence of tourist attraction and word of mouth to tourists' visiting decision in city forest park of Kota Langsa. Samples of this research are 96 respondents. Data analysis of this research is using multiple linear regression method and hypothesis testing is using t-test, f-test, and determination coefficient test $\left(R^{2}\right)$. The t-test result shows that partially tourist attraction and word of mouth variables were influenced significantly to tourist's visiting decision in city forest park of Kota Langsa. F-test result shows that both tourist attraction and word of mouth variables were influenced simultaneously and significantly on the tourist's visiting decision in city forest park of Kota Langsa.
\end{abstract}

Keywords: Tourist Attraction, Word of Mouth, Tourist's Visiting Decision.

\section{PENDAHULUAN}

Indonesia merupakan salah satu negara yang terkenal akan keindahan alamnya. Kekayaan budayanya merupakan komponen penting dalam pariwisata. Sektor pariwisata sangat potensial untuk dikembangkan sebagai salah satu pendapatan daerah, karena pada pandangan masyarakat pariwisata sekarang bukan lagi menjadi suatu hal yang asing dan tabu. Kini pariwisata sudah menjadi bagian dari gaya hidup yang dapat dilakukan oleh masyarakat di semua kalangan yang memiliki kebutuhan dan keinginan untuk bepergian atau berekreasi ke suatu daerah tujuan wisata guna meningkatkan kualitas hidupnya.

Keberadaan industri pariwisata sebagai bagian dari sektor ekonomi yang merupakan industri yang sangat menjanjikan dalam menghadapi persaingan industri pada saat ini, bahkan daerah lain terus mengembangkan potensi wisata yang ada didaerahnya untuk menarik minat wisatawan lokal maupun manca negara untuk berkunjung ke daerah itu.

Pariwisata sekarang sudah menjelma menjadi industri yang disebut industri pariwisata yang dapat menghasilkan produk- produk wisata yang dapat dipasarkan.Untuk meningkatkan pariwisata, diperlukan suatu penanganan khusus dan juga diperlukan manajemen yang baik dalam mengelolanya. Investasi di bidang pariwisata akan sangat menjanjikan dalam pertumbuhan ekonomi suatu negara maupun daerah. Langkah yang dilakukan oleh berbagai daerah tidak akan menuju sasaran apabila tidak di dukung oleh sistem pemasaran yang baik.

Salah satu daerah yang pemerintahnya sedang gencar mempromosikan daerahnya adalah Kota Langsa yang mana daerah ini telah dinobatkan sebagai salah satu kota tujuan wisata di Provinsi Aceh, selain Aceh Besar, Sabang, Bener Meriah dan Simeulu. Kota Langsa dengan luas yang relatif kecil dibandingkan dengan kota lain di provinsi Aceh memiliki ciri khas tersendiri yang unik dan menarik serta potensi alam yang beragam yaitu pelabuhan, pantai, kawasan kota, hutan lindung, bukit-bukit, dan tempat wisata yang dimanfaatkan oleh masyarakat dengan usaha dan kreatifitas yang tinggi.

Salah satu andalan objek wisata alam di Kota Langsa saat ini adalah wisata ruang 
terbuka hijau Taman Hutan Kota atau di kenal juga dengan sebutan Hutan Lindung. Taman Hutan Kota ini adalah kawasan wisata dengan konsep ruang terbuka hijau yang juga berfungsi sebagai paru-paru Kota Langsa yang memiliki luas sekitar 48,9 hektare. Namun saat ini pengunjung ruang terbuka hijau Taman Hutan Kota di Kota Langsa mengalami penurunan. Kondisi ini tentunya sangat mengkhawatirkan pengelola ruang terbuka hijau Taman Hutan Kota di Kota Langsa. Penyebab naik turunnya jumlah pengunjung ke ruang terbuka hijau Taman Hutan Kota di Kota Langsa masih terus ditelusuri lebih lanjut oleh pihak pengelola, namun beberapa diantara pengunjung menyatakan keluhannya dari beberapa hal yang mereka rasakan. Hingga saat ini ruang terbuka hijau Taman Hutan Kota di Kota Langsa belum seutuhnya dapat memenuhi keinginan dan harapan pengunjungnya, masih terdapat banyak kekurangan disana sini, dan pengelola juga masih terus mengupayakan semaksimal mungkin guna keberlanjutan objek wisata yang ada.

Pengunjung yang datang ke ruang terbuka hijau Taman Hutan Kota di Kota Langsa kebanyakan berasal dari luar daerah Kota Langsa. Sementara ini papan penunjuk arah menuju lokasi objek wisata di beberapa ruas jalan masih belum memadai, sehingga dapat membingungkan para pengunjung yang ingin berwisata ke ruang terbuka hijau Taman Hutan Kota di Kota Langsa. Transportasi umum menuju lokasi tersebut juga masih sangat terbatas. Ruang terbuka hijau Taman Hutan Kota belum memiliki tempat-tempat atau ruangan beristirahat dan berteduh bagi para pengunjung, sehingga pada saat ketika hujan turun secara tiba-tiba, pengunjung merasa kesulitan untuk berteduh.

Tingkat keamanan disekitar danau buatan sebagai salah satu sarana bermain dirasakan pengunjung masih sangat kurang memadai, sehingga sangat mengkhawatirkan para pengunjung yang membawa anak-anak kecil. Belum tersedianya sarana yang dapat memudahkan bagi para pengunjung terutama bagi pengunjung yang sudah berusia agak lanjut untuk mengitari area ruang terbuka hijau Taman Hutan Kota yang cukup luas.

Taman Hutan Kota juga sempat menjadi headline media masa dan media sosial karena putusnya jembatan gantung akibat kehadiran pengunjung yang terlalu ramai berada di atas jembatan itu dalam waktu yang bersamaan. Sehingga dari permasalahan itu seseorang yang telah memiliki pengalaman berkunjung akan menceritakan pengalamannya tentang ruang terbuka hijau Taman Hutan Kota kepada orang lain, sehingga dari hal tersebut terciptanya word of mouth yang dapat berdampak positif maupun negatif bagi objek wisata tersebut.

\section{Daya Tarik Wisata}

Ismayanti (2009) memaparkan bahwa daya tarik wisata merupakan fokus utama penggerak pariwisata di sebuah destinasi, daya tarik wisata sebagai penggerak utama yang memotivasi wisatawan mengunjungi suatu tempat. Danang (2014) menyatakan informasi dari mulut ke mulut (word of mouth) ialah pelanggan akan berbicara kepada pelanggan lain atau masyarakat lainnya tentang pengalamannya menggunakan produk yang dibelinya.

Suwena dan Widyatmaja (2017) menyatakan wisatawan dalam melakukan aktivitas perjalanannya itu dirangsang atau ditimbulkan oleh adanya "sesuatu yang menarik", yang lazim disebut daya tarik wisata (tourism attraction, tourist attraction), yang dimiliki tempat kunjungan tersebut, baik untuk kepentingan bisnisnya maupun sebagai tempat pesiar, misalnya iklim tropis yang hangat, iklim ekonomi yang kondusif buat investasi, maupun kegiatan lainnya.

Zaenuri (2012) menyatakan attraksi wisata atau daya tarik wisata merupakan pertunjukan atau atraksi yang unik dan menjadi preferensi dari para wisatawan dan akhirnya bisa memuaskan apa yang diinginkan oleh wisatawan itu. Zaenuri (2012) mengatakan atraksi adalah obyek atau daya tarik wisata yakni objek yang memiliki daya tarik untuk dilihat, ditonton, dinikmati yang layak untuk dijual ke pasar wisata. 
Zaenuri (2012) menyatakan bahwa di dalam sistem kepariwisataan terdapat empat indikator tujuan wisata yang saling mendukung. Pertama adalah Attractions atau daya tarik wisata, yang secara umum dapat dipilah dalam daya tarik alam, daya tarik budaya, dan daya tarik buatan. Kedua adalah Amenities atau fasilitas serta layanan pendukung wisata, yang antara lain meliputi akomodasi dan jasa boga, serta aneka jasa lain, termasuk retail dan jasa rekreasi lainnya. Ketiga adalah Access atau pencapaian, baik menuju ke maupun di dalam daerah tujuan. Keempat adalah Ancillary Services, yang meliputi kegiatan pemasaran, pengembangan, serta koordinasi.

\section{Word of Mouth}

Danang (2014) menyatakan informasi dari mulut ke mulut (word of mouth) ialah pelanggan akan berbicara kepada pelanggan lain atau masyarakat lainnya tentang pengalamannya menggunakan produk yang dibelinya. Hasan (2010) menyatakan word of mouth merupakan pujian, rekomendasi, dan komentar pelanggan di sekitar pengalaman mereka atas layanan jasa dan produk yang betul-betul mempengaruhi keputusan atau perilaku pembelian mereka. Mowen dan Minor (2008) mendefinisikan komunikasi dari mulut ke mulut (word of mouth communication) mengacu pada pertukaran komentar, pemikiran atau ide-ide diantara dua konsumen atau lebih, yang tak satupun merupakan sumber pemasaran. Rangkuti (2009) mendefinisikan word of mouth (WOM) sebagai usaha pemasaran yang memicu pelanggan untuk membicarakan, mempromosikan, merekomendasikan dan menjual suatu produk, jasa atau merek kepada pelanggan lain. Sedangkan Sumardy (2011) menyatakan word of mouth adalah "the act of consumers providing information to order consumers atau C-2-C (Consumer-to-Consumer)", yang artinya: "tindakan penyediaan informasi oleh konsumen kepada konsumen lain".

Widjaja (2016) memaparkan bahwa word of mouth dapat diukur dengan menggunakan beberapa indikator. Pertama adalah Membicarakan, yaitu .kemauan seseorang untuk membicarakan hal-hal positif tentang kualitas produk kepada orang lain. Kedua adalah Merekomendasikan, yaitu konsumen menginginkan produk yang bisa memuaskan dan memiliki keunggulan dibandingkan dengan orang lain, sehingga bisa direkomendasikan kepada orang lain. Ketiga adalah Mendorong, yaitu dorongan terhadap teman atau relasi untuk melakukan transaksi atas produk dan jasa. Konsumen menginginkan timbal balik yang menarik pada saat mempengaruhi orang lain untuk memakai produk atau jasa yang telah diberitahukan.

Hasan (2010) mengemukakan bahwa word of mouth memiliki fungsi. Fungsi yang pertama adalah word of mouth sebagai sumber informasi yang independen dan jujur, yang artinya ketika seorang datang dari teman itu lebih kredibel karena tidak ada keterkaitan dari orang tersebut dengan perusahaan produk tersebut. Fungsi kedua adalah word of mouth sebagai sumber yang sangat kuat karena memberikan manfaat kepada yang bertanya dengan memperoleh pengalaman langsung melalui pengalaman teman. Fungsi ketiga adalah word of mouth bila disesuaikan dengan orang-orang yang tertarik didalamnya seseorang tidak akan bergabung dengan percakapan, kecuali jika mereka tertarik pada topik yang disukainya. Fungsi keempat adalah word of mouth yang menghasilkan informasi media informasi. Fungsi kelima yaitu word of mouth yang dapat mulai dari satu sumber tergantung bagaimana kekuatan influencer dan jaringan sosial itu menyebar dengan cepat dan secara luas kepada orang lain. Terakhir adalah fungsi word of Mouth yang tidak dibatasi oleh ruang atau kendala lainnya, seperti ikatan sosial, waktu, keluarga atau hambatan fisik lainnya.

\section{Keputusan Wisatawan Berkunjung}

Keputusan wisatawan berkunjung dianalogikan serupa dengan bentuk keputusan pembelian, hal ini dikarenakan dalam konteks pariwisata, memutuskan untuk membeli suatu produk wisata sama halnya dengan melakukan keputusan berkunjung. Kotler dan Keller (2009) mengemukakan keputusan adalah tahap dalam proses pengambilan keputusan dimana konsumen benar-benar 
membeli. Laksana (2008) mengemukakan keputusan pembelian merupakan proses dalam pembelian yang nyata, yaitu apakah membeli atau tidak.

Schiffman dan Kanuk (2009) mengemukakan bahwa keputusan pembelian adalah pemilihan dari dua atau lebih alternatif pilihan dalam melakukan penelitian. Setiadi (2010) menyatakan keputusan pembelian adalah proses pengintegrasian yang mengkombinasi sikap pengetahuan untuk mengevaluasi dua atau lebih perilaku alternatif dan memilih salah satu diantaranya. Suryani (2008) menyatakan pengambilan keputusan dapat dipandang sebagai suatu sistem yang terdiri dari input, proses dan output.

\section{Tahap Keputusan Wisatawan Berkunjung}

Kotler dan Amstrong (2008) menyatakan proses keputusan pembelian meliputi beberapa tahapan. Tahap pertama adalah Pengenalan Kebutuhan, dimana pembeli mengenali adanya masalah atau kebutuhan; atau pembeli merasakan perbedaan antara keadaan nyata dan keadaan yang diinginkan. Kebutuhan dapat dipicu oleh rangsangan internal (dari dalam diri) dan rangsangan eksternal (lingkungan). Tahap kedua adalah Pencarian Informasi, yaitu tahap seorang konsumen yang sudah tertarik mungkin mencari informasi lebih banyak informasi, tetapi mungkin juga tidak. Tahap ketiga adalah Evaluasi Alternatif, dimana pada tahap ini konsumen dihadapkan pada beberapa pilihan produk yang akan dibelinya. Tahap keempat adalah Keputusan Membeli, yang merupakan tahap dari proses keputusan membeli yaitu ketika konsumen benar-benar membeli produk. Tahap terakhir adalah Tingkah Laku Pasca Pembelian, dimana setelah membeli poduk, konsumen akan merasa puas atau tidak puas terhadap barang yang dibeli.

\section{Hipotesis}

Berdasarkan latar belakang dan rumusan masalah, hipotesis yang diajukan dalam penelitian ini adalah:

1. Terdapat pengaruh dari daya tarik wisata terhadap keputusan wisatawan berkunjung ke Taman Hutan Kota di Kota Langsa.
2. Terdapat pengaruh dari word of mouth terhadap keputusan wisatawan berkunjung ke Taman Hutan Kota di Kota Langsa.

3. Terdapat pengaruh dari daya tarik wisata dan word of mouth terhadap keputusan wisatawan berkunjung ke Taman Hutan Kota di Kota Langsa.

\section{METODE PENELITIAN}

Penelitian ini termasuk dalam ruang lingkup ilmu manajemen pemasaran dengan variabel daya tarik wisata, word of mouth dan keputusan wisatawan berkunjung. Lokasi penelitian adalah objek wisata ruang terbuka hijau Taman Hutan Kota di Kota Langsa.

Jenis data yang digunakan adalah data kualitatif dan kuantitatif. Data kualitatif yaitu metode penelitian yang berlandaskan pada filsafat postpositivisme, digunakan untuk meneliti pada kondisi obyek yang alamiah, sebagai lawannya adalah eksperimen sebagai instrumen kunci, teknik pengumpulan data ditentukan secara triangulasi (gabungan), analisis data bersifat induktif/kualitatif, dan hasil penelitian kualitatif lebih menekankan makna daripada generalisasi (Sugiyono, 2010). Data kualitatif pada penelitian ini diperoleh melalui analisis dokumen dan observasi pada objek penelitian. Data Kuantiatif adalah metode yang berlandaskan pada filsafat positivisme, digunakan untuk meneliti pada populasi atau sampel tertentu, pengumpulan data menggunakan instrumen penelitian, analisis data bersifat kuantitatif/ statistik, dengan tujuan untuk menguji hipotesis yang telah ditetapkan (Sugiyono, 2010). Data kuantitatif pada penelitian ini merupakan data yang berupa angka, dimana data ini berasal dari hasil kuesioner yang disebarkan kepada responden.

Sumber data meiputi data primer dan data sekunder. Sumber Primer adalah sumber data yang langsung memberikan data kepada pengumpul data (Sugiyono, 2010). Pada penelitian ini data primer diperoleh dari data jumlah pengunjung yang diperoleh dari kantor Dinas Pemuda, Olah raga, dan Pariwisata (DISPORAPAR) dan PT. Pelabuhan Kota Langsa (PEKOLA) sebagai pengembang pariwisata ruang terbuka hijau Taman Hutan Kota di Kota Langsa. Data Sekunder adalah 
sumber yang tidak langsung memberikan data kepada pengumpul data, misalnya lewat orang lain atau lewat dokumen (Sugiyono, 2010). Pada penelitian ini data sekunder diperoleh dari buku-buku, jurnal, referensi, surat kabar dan teori atau informasi yang berhubungan dengan penelitian ini.

Populasi pada penelitian ini merupakan wisatawan yang berkunjung pada objek wisata ruang terbuka hijau Taman Hutan Kota di Kota Langsa tahun 2018 yang berjumlah 405.189 orang pengunjung. Penentuan sampel menggunakan teknik non probability sampling dengan teknik accidental sampling dalam menentukan siapa yang akan dijadikan sampel. Karena anggota populasi yang berkunjung ada yang lebih dari satu kali kunjungan, maka jumlah orang yang berkunjung tidak diketahui secara pasti, maka digunakan rumus unknown population, dengan tingkat keyakinan sampel yang dibutuhkan dalam penelitian sebesar $95 \%$ sehingga diperoleh $\mathrm{Z}$ sebesar 1,96; serta tingkat kesalahan yang dapat ditolerir (margin of error) ditentukan sebesar 5\% atau 0,05 (Prasetya, 2011). Berdasarkan perhitungan, diperoleh jumlah sampel dalam penelitian ini adalah 96 orang.

Metode pengumpulan data penelitian terdiri dari observasi, wawancara, dan kuesioner. Observasi pada penelitian ini dilakukan di ruang terbuka hijau Taman Hutan Kota di Kota Langsa. Wawancara merupakan komunikasi langsung dilakukan dengan pengunjung serta direktur dan karyawan PT. Pelabuhan Kota Langsa (PEKOLA) sebagai pengembang pariwisata ruang terbuka hijau Taman Hutan Kota di Kota Langsa. Kuesioner adalah seperangkat pertanyaan atau pernyataan tertulis yang diberikan pada kepada responden untuk dijawab (Sugiyono, 2010), menggunakan skala Likert skala-5 dengan rentang skor 5 untuk jawaban "Sangat Setuju" sampai skor 1 untuk jawaban "Sangat Tidak Setuju".

Pelaksanaaan analisis data dimulai dengan uji validitas dan reliabilitas. Uji validitas menggunakan korelasi bivariate antar masing-masing skor indikator dengan total skor konstruk (Ghozali 2012). Uji reliabilitas atas kuesioner dalam penelitian ini menggunakan Cronbach Alpha, dimana suatu konstruk dikatakan reliabel jika memberikan nilai Cronbach Alpha lebih besar dari 0,70 (Ghozali, 2012).

Kuesioner disebarkan secara online menggunakan google forms yang dibagikan kepada 15 wisatawan secara online dan 15 wisatawan secara offline menggunakan angket. Kuesioner online maupun offline diberikan kepada wisatawan yang pernah mengunjungi objek wisata ruang terbuka hijau Taman Hutan Kota di Kota Langsa pada tahun 2018.

Selanjutnya dilakukan uji regresi linier berganda yang bertujuan untuk mengetahui pengaruh antara daya tarik wisata dan word of mouth terhadap keputusan wisatawan berkunjung ke Taman Hutan Kota di Kota Langsa. Variabel terikat (Y) yaitu Keputusan Wisatawan Berkunjung; sementara variabel bebas terdiri dari Daya Tarik Wisata $\left(\mathrm{X}_{1}\right)$ serta Word of Mouth $\left(\mathrm{X}_{2}\right)$.

Uji hipotesis meliputi uji signifikansi secara parsial (uji t atau t-test) serta uji signifikansi secara simultan (uji $\mathrm{F}$ atau $F$ test). Uji statistik $t$ pada dasarnya menunjukkan seberapa jauh pengaruh satu variabel penjelas/independen secara individual dalam menerangkan variasi variabel dependen (Ghozali, 2012); dengan kriteria pengambilan keputusan quick look bila jumlah degree of freedom (df) adalah 20 atau lebih dan derajat kepercayaan sebesar 5\%, maka $\mathrm{H}_{0}$ yang menyatakan bi $=0$ dapat ditolak (dalam nilai absolut), atau dengan kata lain bahwa kita menerima hipotesis alternatif yang menyatakan bahwa suatu variabel independen secara individu mempengaruhi variabel dependen (Ghozali, 2012).

Uji statistik $F$ menunjukkan apakah semua independen yang dimasukkan dalam model mempunyai pengaruh secara bersamasama terhadap variabel dependen/terikat; dengan kriteria pengambilan keputusan quick look bila nilai $F$ lebih besar dari 4 maka $\mathrm{H}_{0}$ dapat ditolak pada derajat kepercayaan $5 \%$, atau dengan kata lain bahwa kita menerima hipotesis alternatif yang menyatakan semua variabel independen secara serentak dan 
signifikan mempengaruhi variabel dependen (Ghozali, 2012).

\section{HASIL ANALISIS \\ Hasil Uji Validitas dan Reliabilitas}

Untuk memastikan kesahihan dari kuesioner yang digunakan sebagai instrumen pengumpulan data, maka perlu dilakukan pengujian atas derajat validitas dan reliabilitas dari kuesioner yang bersangkutan.

Tabel 1 menunjukkan rangkuman hasil uji validitas atas setiap item pernyataan terkait variabel penelitian. Berdasarkan hasil yang diperoleh teridentifikasi bahwa nilai r-hitung dari setiap item pernyataan adalah lebih besar dari r-tabel, sehingga dinyatakan bahwa kuesioner yang digunakan dalam penelitian ini adalah memenuhi kriteria valid dan bisa digunakan sebagai instrumen pengumpulan data riil.

Berikutnya, Tabel 2 menunjukkan hasil uji reliabilitas atas setiap variabel penelitian. Berdasarkan hasil pengolahan diperoleh nilai Cronbach Alpha untuk masing-masing variabel yang dianalisis adalah lebih besar dari kriteria nilai sebesar 0,6. Dengan demikian dinyatakan bahwa kuesioner yang digunakan dalam penelitian ini adalah memenuhi kriteria reliabel dan bisa digunakan sebagai instrumen pengumpulan data riil.

Tabel 1. Hasil Uji Validitas

\begin{tabular}{ccccc}
\hline & $\mathrm{X}_{1} .1$ & 0,507 & 0,361 & Valid \\
Daya Tarik & $\mathrm{X}_{1} .2$ & 0,427 & 0,361 & Valid \\
Wisata & $\mathrm{X}_{1} .3$ & 0,588 & 0,361 & Valid \\
$(\mathrm{X} 1)$ & $\mathrm{X}_{1} .4$ & 0,669 & 0,361 & Valid \\
& $\mathrm{X}_{1.5}$ & 0,580 & 0,361 & Valid \\
& $\mathrm{X}_{1} .6$ & 0,555 & 0,361 & Valid \\
\hline & $\mathrm{X}_{2} .1$ & 0,701 & 0,361 & Valid \\
Word of Mouth & $\mathrm{X}_{2} .2$ & 0,631 & 0,361 & Valid \\
(X2) & $\mathrm{X}_{2} .3$ & 0,772 & 0,361 & Valid \\
& $\mathrm{X}_{2} .4$ & 0,669 & 0,361 & Valid \\
& $\mathrm{X}_{2} .5$ & 0,807 & 0,361 & Valid \\
& $\mathrm{X}_{2} .6$ & 0,754 & 0,361 & Valid \\
\hline Keputusan & $\mathrm{Y} .1$ & 0,741 & 0,361 & Valid \\
Wisatawan & $\mathrm{Y} .2$ & 0,691 & 0,361 & Valid \\
Berkunjung & $\mathrm{Y} .3$ & 0,635 & 0,361 & Valid \\
(Y) & $\mathrm{Y} .4$ & 0,518 & 0,361 & Valid \\
& $\mathrm{Y} .5$ & 0,494 & 0,361 & Valid \\
& $\mathrm{Y} .6$ & 0,442 & 0,361 & Valid \\
\hline
\end{tabular}

Sumber: Data Primer Diolah, 2019

Tabel 2. Hasil Uji Reliabilitas

\begin{tabular}{lcc}
\hline \multicolumn{1}{c}{ Variabel } & Cronbach Alpha & Keterangan \\
\hline Daya Tarik Wisata $\left(\mathrm{X}_{1}\right)$ & 0,710 & Reliabel \\
Word of Mouth $\left(\mathrm{X}_{2}\right)$ & 0,781 & Reliabel \\
Keputusan Wisatawan Berkunjung $(\mathrm{Y})$ & 0,738 & Reliabel \\
\hline
\end{tabular}

Sumber: Data Primer Diolah, 2019 
Tabel 3. Hasil Regresi Berganda dan Uji t

\begin{tabular}{|c|c|c|c|c|c|c|}
\hline \multirow{2}{*}{\multicolumn{2}{|c|}{ Model }} & \multicolumn{2}{|c|}{$\begin{array}{c}\text { Unstandardized } \\
\text { Coefficients }\end{array}$} & \multirow{2}{*}{$\begin{array}{c}\begin{array}{c}\text { Standardized } \\
\text { Coefficient }\end{array} \\
\text { B }\end{array}$} & \multirow[t]{2}{*}{$\mathbf{t}$} & \multirow[t]{2}{*}{ Sig. } \\
\hline & & B & Std. Error & & & \\
\hline \multirow[t]{3}{*}{1} & (Constant) & 1,200 & 0,414 & & 2.896 & 0,005 \\
\hline & Daya Tarik Wisata $\left(\mathrm{X}_{1}\right)$ & 0,341 & 0,111 & 0,328 & 3.069 & 0,003 \\
\hline & Word of Mouth $\left(\mathrm{X}_{2}\right)$ & 0,317 & 0,118 & 0,287 & 2.683 & 0,009 \\
\hline
\end{tabular}

${ }^{\mathrm{a}}$ Dependent Variable: Kepts Bekunjung

Sumber: Data Primer Diolah, 2019

Tabel 4. Hasil Uji F

\begin{tabular}{|c|c|c|c|c|c|c|}
\hline \multicolumn{2}{|c|}{ Model } & Sum of Squares & df & Mean Square & $\mathbf{F}$ & Sig. \\
\hline 1 & Regressions & 4,971 & 2 & 2,486 & 20,012 &, $000^{\mathrm{b}}$ \\
\hline & Residual & 11,552 & 93 &, 124 & & \\
\hline & Total & 16,523 & 95 & & & \\
\hline
\end{tabular}

${ }^{\mathrm{a}}$ Predictors: (Constant), Daya Tarik Wisata, Word of Mouth

${ }^{b}$ Dependent Variable: Kepts Berkunjung

Sumber: Data Primer Diolah, 2019

\section{Hasil Analisis Regresi Berganda}

Berdasarkan hasil pengolahan dalam Tabel 3 maka bisa disusun persamaan regresi berganda untuk penelitian ini adalah:

$$
Y=1,200+0,341 X_{1}+0,317 X_{2}
$$

Berdasarkan persamaan tersebut bida dinyatakan beberapa hal. Pertama, nilai kostanta sebesar 1,200 adalah nilai keputusan wisatawan berkunjung apabila daya tarik wisata dan word of mouth bernilai tetap atau tidak mengalami perubahan. Kedua, nilai koefisien regresi daya tarik wisata sebesar 0,341 dan bertanda positif, artinya apabila daya tarik wisata meningkat maka keputusan wisatawan berkunjung juga akan meningkat, atau sebaliknya apabila daya tarik wisata menurun maka keputusan wisatawan untuk berkunjung juga menurun; dengan asumsi jika pengaruh word of mouth bernilai tetap. Ketiga, nilai koefisien regresi untuk word of mouth sebesar 0,317 dan bertanda positif, artinya apabila word of mouth meningkat maka keputusan wisatawan berkunjung juga akan meningkat, atau sebaliknya apabila word of mouth menurun maka keputusan wisatawan untuk berkunjung juga menurun; dengan asumsi jika pengaruh daya tarik wisata bernilai tetap.

\section{Hasil Uji Hipotesis}

Uji hipotesis yang dilakukan dalam penelitian ini mencakup Uji t ( $t$-test) dan Uji $\mathrm{F}(F$-test $)$.

Tabel 3 menunjukkan rangkuman hasil uji t berkenaan dengan pengaruh parsial dari variabel bebas terhadap variabel terikat, dan menyatakan dua hasil uji hipotesis. Pertama, hasil uji t antara daya tarik wisata $\left(\mathrm{X}_{1}\right)$ dengan keputusan wisatawan berkunjung (Y) menunjukkan nilai Sig. t sebesar 0,003. Karena nilai Sig. $\mathrm{t}<0,05$ maka dinyatakan bahwa pengaruh daya tarik wisata $\left(\mathrm{X}_{1}\right)$ terhadap keputusan wisatawan berkunjung adalah signifikan. Dengan kata lain, disimpulkan bahwa keputusan wisatawan berkunjung terbukti dipengaruhi secara signifikan oleh daya tarik wisata atau dengan meningkatkan daya tarik wisata maka keputusan wisatawan berkunjung akan mengalami peningkatan secara nyata.

Kedua, hasil uji t antara word of mouth $\left(\mathrm{X}_{2}\right)$ dengan keputusan wisatawan berkunjung (Y) menunjukkan nilai Sig. $t$ sebesar 0,009. Karena nilai Sig. $\mathrm{t}<0,05$ maka dinyatakan bahwa pengaruh word of mouth $\left(\mathrm{X}_{2}\right)$ terhadap keputusan wisatawan berkunjung adalah signifikan. Dengan kata lain, disimpulkan bahwa keputusan wisatawan berkunjung terbukti dipengaruhi secara signifikan oleh 
word of mouth $\left(\mathrm{X}_{2}\right)$ atau bahwa meningkatkan word of mouth $\left(\mathrm{X}_{2}\right)$ maka keputusan wisatawan berkunjung akan mengalami peningkatan secara nyata.

Selanjutnya, hasil uji $\mathrm{F}$ menunjukkan nilai Sig. F sebesar 0,000. Karena nilai Sig. F < 0,05 maka dapat dinyatakan bahwa variabel-variabel independen yang meliputi daya tarik wisata $\left(\mathrm{X}_{1}\right)$ dan word of mouth $\left(\mathrm{X}_{2}\right)$ secara simultan terbukti memiliki pengaruh yang signifikan atas keputusan wisatawan berkunjung ke Taman Hutan Kota di Kota Langsa.

\section{Hasil Koefisien Determinasi}

Berdasarkan Tabel 5 diperoleh nilai $R$ Square $\left(\mathrm{R}^{2}\right)$ sebesar 0,301. Hasil ini menyatakan variabel-variabel independen yang dicakup dalam model penelitian ini memberi kontribusi sebesar $30,1 \%$ untuk menjelaskan pengaruh terhadap keputusan wisatawan berkunjung ke Taman Hutan Kota di Kota Langsa. Sedangkan sisanya sebesar $69,9 \%$ dijelaskan oleh variasi sebab-sebab lain diluar variabel yang diteliti dalam penelitian ini.

\section{Pembahasan}

Dalam bagian ini dibahas mengenai pengaruh dari masing-masing variabel bebas terhadap variabel terikat.

\section{Pengaruh Daya Tarik Wisata terhadap Keputusan Wisatawan Berkunjung}

Hasil uji regresi linier berganda menerangkan bahwa daya tarik wisata pada penelitian ini berpengaruh signifikan terhadap keputusan wisatawan berkunjung ke Taman Hutan Kota di Kota Langsa. Besarnya pengaruh daya tarik wisata menunjukkan nilai terdapat pengaruh yang positif dan signifikan antara daya tarik wisata terhadap keputusan wisatawan berkunjung ke Taman Hutan Kota di Kota Langsa. Oleh karena itu maka dapat disimpulkan $\mathrm{H}_{0}$ ditolak dan $\mathrm{H}_{1}$ diterima; atau, bahwa penelitian ini membuktikan faktor daya tarik wisata memiliki pengaruh yang signifikan terhadap keputusan wisatawan untuk berkunjung ke area wisata tersebut.

Hasil penelitian ini sesuai dengan penelitian sebelumnya yang dilakukan oleh Lapian et al. (2015) menemukan bahwa secara parsial daya tarik wisata berpengaruh signifikan terhadap keputusan wisatawan mengunjungi obyek wisata Pantai Firdaus di Kabupaten Minahasa Utara. Setiyorini et al. (2018) menyatakan bahwa secara parsial daya tarik wisata berpengaruh signifikan terhadap keputusan berkunjung wisatawan obyek wisata Gunung Beruk Karangpatihan Balong.

\section{Pengaruh Word of Mouth terhadap Keputusan Wisatawan Berkunjung}

Hasil uji regresi linier berganda menerangkan bahwa word of mouth pada penelitian ini berpengaruh signifikan terhadap keputusan wisatawan berkunjung ke Taman Hutan Kota di Kota Langsa. Hasil uji parsial menunjukkan bahwa terdapat pengaruh yang positif dan signifikan antara word of mouth terhadap keputusan wisatawan berkunjung ke Taman Hutan Kota di Kota Langsa. Oleh karena itu dapat disimpulkan $\mathrm{H}_{0}$ ditolak dan $\mathrm{H}_{1}$ diterima; atau, bahwa penelitian ini membuktikan faktor word of mouth memiliki pengaruh yang signifikan terhadap keputusan wisatawan berkunjung ke area wisata itu.

Hasil penelitian ini sesuai dengan penelitian sebelumnya yang dilakukan oleh Rahmawati et al. (2016) menyatakan bahwa secara parsial word of mouth berpengaruh signifikan terhadap keputusan berkunjung, dengan studi pada pengunjung Pantai Balekambang-Malang. Setiyorini et al. (2018) menyatakan bahwa secara parsial variabel word of mouth berpengaruh signifikan terhadap keputusan berkunjung wisatawan obyek wisata Gunung Beruk Karangpatihan Balong.

Tabel 5. Hasil Koefisien Determinasi

\begin{tabular}{|c|c|c|c|}
\hline $\mathbf{R}$ & R Square & Adjust R Square & Standard Error of the Estimate \\
\hline $0,549^{\mathrm{a}}$ & 0,301 & 0,286 & 0,35243 \\
\hline
\end{tabular}




\section{Pengaruh Daya Tarik Wisata dan Word of Mouth secara Simultan atas Keputusan Wisatawan Berkunjung}

Berdasarkan hasil penelitian dapat diketahui bahwa daya tarik wisata dan word of mouth memiliki pengaruh terhadap keputusan wisatawan berkunjung. Besarnya pengaruh variabel bebas secara simultan berdasarkan hasil uji $\mathrm{F}$ dinyatakan bahwa variabel-variabel independen dalam penelitian ini yang meliputi daya tarik wisata dan word of mouth memiliki pengaruh simultan yang signifikan tkeputusan wisatawan berkunjung ke Taman Hutan Kota di Kota Langsa.

Hasil penelitian ini sesuai dengan penelitian sebelumnya yang dilakukan oleh Lapian et al. (2015) menyatakan bahwa secara simultan daya tarik wisata berpengaruh signifikan terhadap keputusan wisatawan mengunjungi obyek wisata Pantai Firdaus di Kabupaten Minahasa Utara. Rahmawati et al. (2016) menyatakan bahwa secara simultan word of mouth berpengaruh signifikan terhadap keputusan berkunjung (studi pada pengunjung Pantai Balekambang, Malang). Setiyorini et al. (2018) menyatakan bahwa secara simultan variabel daya tarik wisata dan word of mouth berpengaruh signifikan atas keputusan berkunjung wisatawan obyek wisata Gunung Beruk Karangpatihan Balong.

\section{KESIMPULAN}

Berdasarkan hasil-hasil penelitian yang diperoleh, maka disimpulkan beberapa hal. Pertama, variabel daya tarik wisata berpengaruh signifikan terhadap keputusan wisatawan berkunjung ke Taman Hutan Kota di Kota Langsa, dan merupakan variabel yang lebih besar pengaruhnya terhadap keputusan wisatawan berkunjung ke Taman Hutan Kota di Kota Langsa. Kedua, variabel word of mouth berpengaruh signifikan terhadap keputusan wisatawan berkunjung ke Taman Hutan Kota di Kota Langsa. Ketiga, daya tarik wisata dan word of mouth secara simultan berpengaruh signifikan terhadap keputusan wisatawan berkunjung ke Taman Hutan Kota di Kota Langsa.

Ringkasnya, keputusan wisatawan berkunjung ke Taman Hutan Kota di Kota Langsa hanya relatif kecil dapat dijelaskan oleh daya tarik wisata dan word of mouth; sementara sebagian besar dijelaskan oleh variabel-variabel lain yang tidak dicakup dalam model penelitian ini.

Berdasarkan kesimpulan tersebut makan direkomendasikan beberapa hal. Pertama direkomendasikan agar Pemerintah Kota Langsa khususnya Dinas Pemuda, Olah Raga dan Pariwisata (DISPORAPAR) dan PT. Pelabuhan Kota Langsa (PEKOLA) sebagai pengembang pariwisata Taman Hutan Kota di Kota Langsa harus terus saling bekerja sama terutama berkenaan dengan promosi yang berbentuk advertising serta penyediaan dan penambahan fasilitas.

Rekomendasi kedua adalah perlu adanya penunjuk arah pada beberapa jalur menuju lokasi agar lebih memudahkan pengunjung menjangkau lokasi Taman Hutan Kota di Kota Langsa. Ketiga, sebaiknya tersedia pemandu wisata yang dapat menjelaskan atau memberi edukasi tentang objek wisata disertai dengan penambahan papan edukasi untuk menjelaskan tentang keberadaan flora dan fauna di Taman Hutan Kota di Kota Langsa. Keempat, hendaknya rutin mengadakan event-event, sehingga secara tidak langsung dapat menimbulkan promosi word of mouth.

Rekomendasi kelima adalah hendaknya menambah variasi fauna sehingga dapat menambah daya tarik wisatawan untuk berkunjung sekaligus mengurangi kebosanan para wisatawan yang melakukan kunjungan ulang. Keenam direkomendasikan bahwa sebaiknya menyediakan kotak saran, agar pengunjung yang ingin memberi saran dan masukan dapat tersampaikan.

Terakhir, kiranya diharapkan kepada peneliti lain dapat melakukan penelitian lanjutan untuk mengetahui variabel-variabel lainyang mempengaruhi keputusan wisatawan berkunjung ke Taman Hutan Kota di Kota Langsa, karena dari hasil penelitian daya tarik wisata dan word of mouth hanya memberikan kontribusi relatif kecil sehingga perlu dicari variabel lain yang mempengaruhi keputusan wisatawan berkunjung di luar dari daya tarik wisata dan word of mouth. 


\section{DAFTAR PUSTAKA}

Ghozali, I. 2012. Aplikasi Analisis Multivariate dengan Program IBM SPSS 20. Semarang: Badan Penerbit Universitas Diponegoro.

Hasan, A. 2010. Marketing dari Mulut Ke

Mulut. Yogyakarta: Media Pressindo.

Ismayanti. 2009. Pengantar Pariwisata. Jakarta: Grasindo.

Kotler, P. dan Amstrong, G. 2011. PrinsipPrinsip Pemasaran. Jakarta: Erlangga.

Kotler, P. dan Keller, K.L. 2010. Manajemen Pemasaran. Jakarta: Erlangga.

Laksana, F. 2008. Manajemen Pemasaran. Yogyakarta: Graha Ilmu.

Lapian, S.Q.W., Mandey, S. dan Loindong, S. 2015. Pengaruh Advertising dan Daya Tarik Wisata terhadap Keputusan Wisatawan Mengunjungi Obyek Wisata Pantai Firdaus di Kabupaten Minahasa Utara. Jurnal Emba. Vol. 3, No. 3, hal. 1079-1088.

Mowen, J. dan Minor, M. 2008. Perilaku Konsumen. Jakarta: Erlangga.

Prasetya. 2011. Metode Penelitian Kuantitatif. Jakarta: Rajawali Pers.

Rahmawati, Sunarti, S. dan Pangestuti, E. 2016. Pengaruh Customer Value dan Word of Mouth terhadap Keputusan Berkunjung: Studi pada Pengunjung Pantai Balekambang, Malang. Jurnal Administrasi Bisnis. Vol. 40, No. 1, hal. 112-118.

Rangkuti, F. 2009. Strategi Promosi yang Kreatif. Jakarta: Gramedia Pustaka Utama.

Republik Indonesia. 2009. Undang-Undang No. 10 Tahun 2009 tentang Kepariwisataan. Jakarta.

Schiffman, L.G. dan Kanuk, L.L. 2009. Perilaku Konsumen. Jakarta: PT. Indeks Group Gramedia.
Sernovitz. 2009. Word of Mouth Marketing, Jakarta: Gramedia Pustaka Utama.

Setiadi, N.J. 2010. Perilaku Konsumen. Jakarta: Kencana.

Setiyorini, A., Farida U. dan Kristiyana, N. 2018. Pengaruh Promosi Melalui Media Sosial, Word of Mouth, dan Daya Tarik Wisata terhadap Keputusan Berkunjung Wisatawan Obyek Wisata Gunung Beruk Karangpatihan Balong. Jurnal Ekonomi, Manajemen dan Akutansi. Vol. 2, No. 1, hal. 12-17.

Sugiyono. 2010. Metode Penelitian Kuantitatif, Kualitatif, dan R\&D. Bandung: Alfabeta.

Sugiyono. 2017. Statistik untuk Penelitian. Bandung: Alfabeta.

Sumardy. 2011. The Power of Word of Mouth Marketing. Jakarta: Gramedia Pustaka Utama.

Sunyoto, D. 2014. Dasar-Dasar Manajemen Pemasaran: Konsep, Strategi, dan Kasus. Yogyakarta: Caps.

Suryani, T. 2008. Perilaku Konsumen, Implikasi pada Strategi Pemasaran. Yogyakarta: Graha Ilmu.

Suwena, I.K. dan Widyatmaja I.G.N. 2017. Pengetahuan Dasar Ilmu Pariwisata. Bali: Pustaka Larasan.

Umar, H. 2008. Metode Penelitian untuk Skripsi dan Tesis Bisnis. Jakarta: PT RajaGrafindo Persada.

Widjaja, A.T. 2016. Pengaruh Word of Mouth dan Electronik Mouth terhadap Purchase Intention: Sebuah Studi Kasus Mengenai Prilaku Konsumen terhadap Jasa Ojek Online Gojek. Jurnal Bisnis dan Manajemen. Vol. 53, No. 12, hal. 241-253.

Zaenuri, M. 2012. Perencanaan Strategis Kepariwisataan Daerah: Konsep dan Aplikasi. Jogjakarta: E-Gov Publishing. 